\title{
DAYA DUKUNG LAHAN UNTUK PEMUKIMAN PENDUDUK DAN IMPLIKASINYA TERHADAP KUALITAS PERAIRAN DI PULAU-PULAU KECIL (KASUS PULAU-PULAU KECIL SELAT TIWORO KABUPATEN MUNA BARAT)
}

\section{LAND CARRYING CAPACITY FOR SETTLEMENT AND ITS IMPLICATIONS ON WATER QUALITY AT SMALL ISLANDS (CASE STUDY OF TIWORO STRAIT SMALL ISLANDS, WEST MUNA REGENCY)}

\author{
Romy Ketjulan ${ }^{1}$, Mennofatria Boer ${ }^{2}$, Zulhamsyah Imran $^{2}$ dan Vincentius P. Siregar ${ }^{3}$ \\ ${ }^{1}$ Program Studi Pengelolaan Sumberdaya Pesisir dan Lautan, FPIK-IPB, Bogor, 16680 \\ ${ }^{2}$ Departemen Manajemen Sumberdaya Perairan, FPIK-IPB, Bogor, 16680 \\ ${ }^{3}$ Departemen Ilmu dan Teknologi Kelautan, FPIK-IPB, Bogor, 16680 \\ *E-mail: romyketjulanuho@gmail.com
}

\begin{abstract}
Small islands are an entity that has limitations to be used. This study aimed to analyze the land carrying capacity for settlement and its implication on water quality at small islands. The carrying capacity of land are determined based on an analysis of the minimum space requirements of each individual according to Indonesian National Standards (SNI) 03-1733-2004, while the implications for water quality are determined based on the nutrient load approach. The results of this research showed that the Tiworo archypelago have a total potential land approximately 198.94 ha and about $31.45 \mathrm{ha}$ of this amount has been utilized. Although the land use is relatively small, however, there are also islands that have been used to exceed their carrying capacity. The human population density of each island has a positive correlation with the level of the land degradation. The total population currently is still tolerated by water bodies, but when the population is suitable with the land carrying capacity will increase the ammonia ratio by 0.086-0.550. This indicates that the land carrying capacity of the Tiworo chained Islands is not higher than the ability of the water body in assimilating the domestic waste.
\end{abstract}

Keywords: carrying capacity, settlements, small islands

\begin{abstract}
ABSTRAK
Pulau-pulau kecil merupakan sebuah entitas yang memiliki keterbatasan untuk dimanfaatkan. Penelitian ini bertujuan untuk menganalisis daya dukung lahan untuk permukiman penduduk dan inplikasinya terhadap kualitas air di pulau-pulau kecil. Daya dukung lahan ditentukan berdasarkan analisis kebutuhan ruang minimum setiap individu sesuai Standar Nasional Indonesia (SNI) 03-17332004, sedangkan implikasinya terhadap kualitas air ditentukan berdasarkan pendekatan beban nutrien. Hasil penelitian menunjukkan bahwa Kepulauan Tiworo memiliki total potensi lahan sebesar 198,94 ha. Lahan yang telah dimanfaatkan sebesar 31,45 ha. Meskipun pemanfaatan lahan relatif tergolong kecil, namun terdapat pulau yang dimanfaatkan telah melebihi daya dukung. Kepadatan penduduk setiap pulau memiliki korelasi positif terhadap tingkat degradasi lahan. Total jumlah penduduk saat ini masih dapat ditolerir badan air, namun jika jumlah penduduk sesuai daya dukung lahan, akan meningkatnya rasio baku mutu amonia sebesar 0,086-0,550. Hal ini menunjukkan bahwa daya dukung lahan gugus Kepulauan Tiworo lebih besar dari kemampuan badan air dalam mengasimilasi limbah domestik.
\end{abstract}

Kata kunci: daya dukung, permukiman penduduk, pulau-pulau kecil 


\section{PENDAHULUAN}

Pemukiman penduduk di pulau kecil merupakan salah satu bentuk pemanfaatan ruang di tengah isu "keterbatasan" pemanfaatan. Selain karena memiliki ukuran yang relatif kecil, keterbatasan pemanfaatan pulau kecil juga dapat dilihat dari aspek ketergantungannya (dependence) terhadap pulau besar, letaknya yang terisolir (insular) atau terpisah dari mainland, dan rentan (vulnerability) terhadap perubahan lingkungan (Bengen et al., 2012). Menurut Fauzi (2002) keterbatasan tersebut merupakan faktor kendala yang harus dipertimbangkan dalam melakukan pengelolaan. Meskipun memiliki keterbatasan, pulau kecil dan perairan sekitarnya menyediakan sumberdaya alam yang cukup beragam dan produktif, seperti terumbu karang, padang lamun, mangrove, berbagai jenis ikan, energi kelautan, dan jasa-jasa lingkungan yang dapat dimanfaatkan untuk memenuhi kebutuhan hidup manusia (Dahuri, 2003). Keberadaan sumberdaya alam dan jasa lingkungan tersebut diduga menjadi pemicu penggunaan ruang di pulau kecil, meskipun akses terhadap transportasi, pendidikan, kesehatan, pasar, teknologi dan informasi masih sangat terbatas.

Selain pemukiman penduduk, jenis kegiatan pemanfaatan ruang yang dapat dilakukan di pulau kecil cukup beragam. Berdasarkan Peraturan Menteri Kelautan dan Perikanan No. 20 tahun 2008 prioritas pemanfaatan pulau kecil diantaranya adalah untuk kepentingan konservasi, pendidikan dan pelatihan, penelitian dan pengembangan, budidaya laut, pariwisata bahari, usaha perikanan dan kelautan, industri perikanan secara lestari, dan pertahanan keamanan. Diantara berbagai jenis kegiatan pemanfaatan yang boleh dilakukan, pengembangan pariwisata bahari adalah kegiatan yang cukup populer, dan merupakan salah satu instrumen pembangunan ekonomi (Kurniawan et al., 2016). Pengembangan kegiatan pertanian yang dikenal dengan istilah agromarine juga merupakan salah satu bentuk pemanfaatan ruang yang dapat dilakukan di pulau kecil. Kebiasaan masyarakat Indonesia bercocok tanam menjadikan aktivitas pertanian selalu berdampingan dengan pemukiman penduduk. Namun demikian lahan untuk kegiatan pertanian cenderung mengalami penurunan akibat bertambahnya luas kawasan pemukiman penduduk (Krisnohadi, 2011).

Sebagai salah satu bentuk pemanfaatan ruang, pemukiman penduduk memiliki konsekwensi terhadap perubahan fungsi lahan. Menurut Rotinsulu et al. (2018) dan Mekonnen et al. (2018) dua kegiatan tersebut merupakan komponen terbesar yang berkaitan erat dengan terjadinya perubahan fungsi lahan. Perubahan fungsi lahan tersebut juga berkaitan dengan peningkatan emisi karbon di udara (Wu et al., 2012). Selain berdampak pada ekosistem darat, pemukiman penduduk di pulau kecil juga menghasilkan limbah domestik yang dapat meningkatkan konsentrasi bahan organik yang terkandung dalam air (Chen, 2018; Cao et al., 2017). Perubahan-perubahan tersebut merupakan implikasi dari kegiatan manusia yang cenderung destruktif terhadap keberadaan sumberdaya, khususnya sumberdaya alam di pulau-pulau kecil.

Meningkatnya jumlah penduduk yang disertai dengan peningkatan kebutuhan manusia merupakan faktor pemicu (driving forces) terhadap penggunaan lahan (Meyer and Turner, 1992; Lambin et al., 2001; Diposaptono, 2015). Selain berimplikasi pada aspek sosial dan ekonomi, pertambahan jumlah penduduk akan terus meningkat sampai pada keadaan dimana daya dukung lingkungan tidak sebanding dengan tekanan yang diberikan. Terjadinya alih fungsi lahan merupakan salah satu konsekuensi logis pertambahan jumlah penduduk yang menyebabkan hilangnya vegetasi daratan, utamanya ekosistem mangrove. Menurut Food and Agriculture Organization (FAO) (2007) Indonesia kehilangan sekitar 40\% luas hutan mangrove akibat alih fungsi menjadi tambak, pemukiman penduduk, industri, dan 
perkebunan. Secara ekologi, hilangnya ekosistem mangrove berarti hilangnya fungsi sebagai spawning ground, feeding ground dan nursery ground berbagai jenis biota laut. Mengingat pemukiman penduduk memiliki konsekuensi terhadap perubahan fungsi lahan di pulau kecil, salah satu upaya yang dilakukan pemerintah saat ini adalah menetapkan kawasan lindung di pulau kecil sebesar 30\% dari luas pulau sebagaimana tertuang dalam Peraturan Menteri Agraria No. 17 tahun 2016.

Sebagai daerah otonom baru yang berusia \pm 4 tahun, Kabupaten Muna Barat membutuhkan berbagai kajian dalam hal pengelolaan pulau-pulau kecil sebagai input dalam penentuan kebijakan. Urgensi kebijakan pengelolaan pulau kecil sangat beralasan karena: (1) karakteristik Kabupaten Muna Barat merupakan wilayah pesisir dan kepulauan, dimana perairan Selat Tiworo merupakan perairan utama yang dapat menghubungkan dengan wilayah lainnya; (2) adanya kegiatan pemanfaatan sumberdaya pulau-pulau kecil yang cukup beragam seperti perikanan tangkap, pemukiman penduduk, rekreasi dan wisata bahari, budidaya laut, dan transportasi. Berdasarkan fenomena pemukiman penduduk di Kepulauan Tiworo, penelitian ini sangat menarik untuk menganalisis keterkaitan pemukiman penduduk terhadap tingkat pemanfaatan lahan, daya dukung, dan implikasinya terhadap kualitas perairan.

\section{METODE PENELITIAN}

\subsection{Lokasi Penelitian}

Penelitian ini dilakukan di gugus Kepulauan Tiworo yang berpenduduk, yakni Pulau Tiga, Pulau Tasipi, Pulau Santigi, Pulau Balu, Pulau Mandike, dan Pulau Bero, Kecamatan Tiworo Utara Kabupaten Muna Barat pada bulan Desember 2017 sampai dengan Juni 2018.

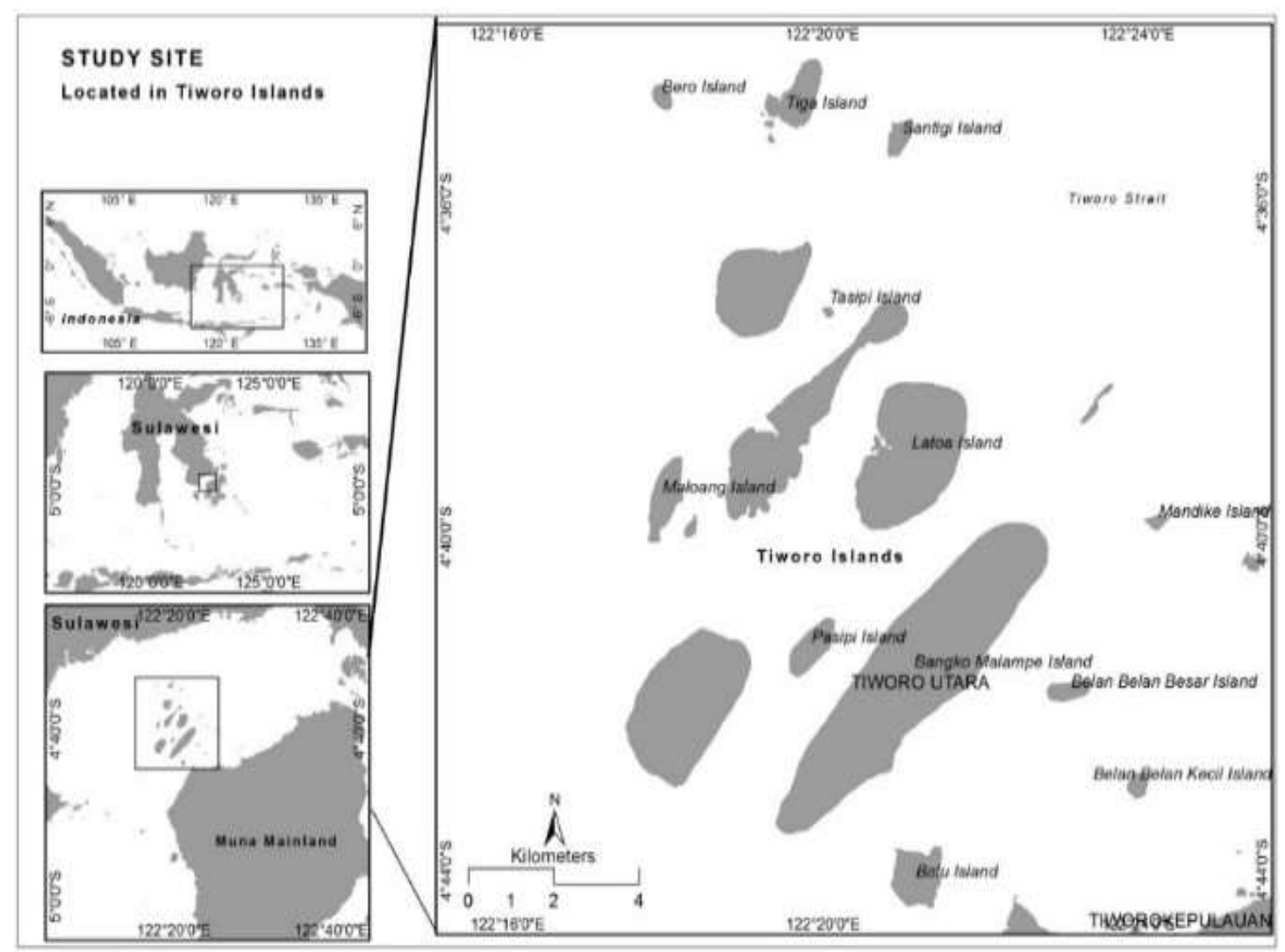

Gambar 1. Lokasi penelitian (Kepulauan Tiworo). 
Potensi dan penggunaan lahan (spasial), dianalisis menggunakan citra satelit SPOT 6 tahun 2016. Analisis daya dukung lahan untuk permukiman penduduk dilakukan dengan pendekatan analisis kebutuhan ruang minimum setiap individu sesuai Standar Nasional Indonesia (SNI) 031733-2004. Implikasi permukiman penduduk terhadap perubahan mutu air dilakukan dengan pendekatan beban nutrien atau keseimbangan masa, yakni membandingkan nilai paremeter kualitas air hasil observasi dengan nilai baku mutu sesuai Keputusan Menteri Negara Lingkungan Hidup No. 51/2004. Data yang digunakan dalam penelitian ini berupa data luas pulau, tutupan lahan, dan data degradasi lahan diperoleh dari analisis citra satelit SPOT 6 tahun 2016. Data dan informasi yang diperoleh dianalisis dengan menggunakan beberapa alat analisis sebagai berikut.

\subsection{Analisis Data}

\subsubsection{Potensi Lahan Pemukiman}

Potensi lahan untuk pemukiman penduduk adalah luas pulau kecil yang dapat dimanfaatkan setelah dikurangi dengan 30\% untuk alokasi kawasan lindung sesuai Pertaruran Menteri Agraria dan Tata Ruang No. 17 tahun 2016. Berdasarkan peraturan tersebut, maka potensi lahan dapat dihitung dengan menggunakan persamaan berikut.

Potensi lahan $=($ luas pulau $\times 0,7)$

\subsubsection{Estimasi Daya Dukung Lahan}

Analisis daya dukung lahan merupakan pendekatan yang bertujuan untuk menentukan jumlah maksimum penduduk di pulau kecil. Jumlah maksimum penduduk pulau kecil ditentukan dengan pendekatan jumlah unit rumah tinggal. Estimasi jumlah unit rumah tinggal ditentukan dengan pendekatan analisis kebutuhan ruang minimum setiap individu sesuai Standar Nasional Indonesia (SNI) 03-1733-2004. Berdasarkan SNI 03-1733-2004 kebutuhan ruang minimum setiap individu sebesar 9,6 $\mathrm{m}^{2}$. Untuk mengestimasi daya dukung lahan pulau kecil sesuai standar SNI dihitung dengan pendekatan sebagai berikut:

Total luas lantai $=$ Luas lantai utama + Luas lantai pelayanan

Luas lantai utama $\quad=9,6 \times \sum$ jiwa per KK Luas lantai pelayanan $=50 \% \quad \mathrm{x}$ luas lantai utama

Koefisien dasar bangunan adalah 50\%, maka kebutuhan kavling minimum setiap KK adalah:

\section{Kebutuhan kavling minimum $=$ $\frac{100}{50} \times$ total luas lantai}

Jika digunakan asumsi bahwa setiap KK terdiri dari 4 jiwa, maka kebutuhan kavling minimum sebesar $115,2 \mathrm{~m}^{2}$. Jika fasilitas umum berupa jalan lokal sekunder dengan lebar $5 \mathrm{~m}$ yang merupakan kelas jalan terendah untuk menghubungkan setiap unit pemukiman, maka jumlah unit bangunan per hektar lahan adalah sebesar 60 unit, yang dapat menampung 240 jiwa.

\subsubsection{Analisis Degradasi Lahan}

Tingkat degradasi lahan yang mencerminkan pemanfaatan sumberdaya lahan pada kondisi eksisting dihitung menggunakan persamaan (Rahman, 2009).

$D L T_{i}=\left(\frac{L T_{i}}{A_{i}}\right) \times 100$

Keterangan:

DLT = degradasi lahan oleh lahan terbangun pulau ke-i $(\%)$; LT = luas lahan terbangun pulau ke-i $\left(\mathrm{km}^{2}\right) ; \mathrm{A} \quad=$ luas pulau kecil ke-i $\left(\mathrm{km}^{2}\right)$.

\subsubsection{Perubahan Mutu Air}

Pendekatan yang digunakan untuk mengestimasi perubahan mutu air didasarkan pada korelasi peningkatan kandungan amonia dalam air dengan peningkatan jumlah 
penduduk. Hasil penelitian Ketjulan et al. (2019) menunjukkan bahwa penduduk di Kepulauan Tiworo berpengaruh secara nyata terhadap parameter amonia di perairan. Pendekatan yang digunakan mengestimasi perubahan mutu air adalah persamaan rasio baku mutu (RBM) sebagai berikut (Pindyck and Rubinfeld, 1998):

$$
\operatorname{RBM}=\mathrm{a}+\mathrm{b}\left(\mathrm{P}_{\mathrm{i}}\right)
$$

Keterangan:

$\mathrm{RBM}=$ Rasio Baku Mutu, $\mathrm{a}=$ konstantra, $\mathrm{b}=$ koefisien regresi, $\mathrm{Pi} \quad=$ jumlah penduduk.

Nilai konstanta dan koefisien regresi untuk menduga nilai rasio baku mutu air mengacu pada hasil perhitungan yang dilakukan oleh Ketjulan et al. (2019). Nilai konstanta yang diperoleh sebesar 0,07, sedangkan nilai koefisien regresi sebesar 2,34 $\mathrm{x} 10^{-5}$. Nilai koefisien regresi sebesar $2,34 \mathrm{x}$ $10^{-5}$ memiliki pengertian bahwa setiap terjadi pertambahan penduduk sebesar satu satuan, akan meningkatkan nilai RBM amonia sebesar 2,34 x $10^{-5}$. Nilai RBM sebesar 1 adalah batas daya dukung, artinya nilai hasil pengukuran parameter kualitas air eksisting sama dengan nilai baku mutu air sesuai Keputusan Menteri Negara Ligkungan Hidup No. 51/2004. Jika nilai RBM > 1 , artinya telah melebihi daya dukung, sebaliknya jika nilai $\mathrm{RBM}<1$ berarti belum melebihi daya dukung perairan.

\section{HASIL DAN PEMBAHASAN}

\subsection{Hasil}

Berdasarkan hasil analisis citra satelit SPOT-6, secara keseluruhan gugus Kepulauan Tiworo yang terletak di Kecamatan Tiworo Utara berjumlah 14 pulau. Ukuran luas pulau bervariasi mulai dari $0,047-14,70 \mathrm{~km}^{2}$. Pulau yang berpenduduk berjumlah 6 pulau, memiliki luas 0,047-1,27 $\mathrm{km}^{2}$. Pulau berpenduduk yang berukuran paling kecil adalah Pulau Tasipi, sedangkan pulau yang berukuran paling besar adalah Pulau Balu. Total luas pulau yang dimanfaatkan sebagai tempat pemukiman penduduk saat ini sebesar $3,07 \mathrm{~km}^{2}$.

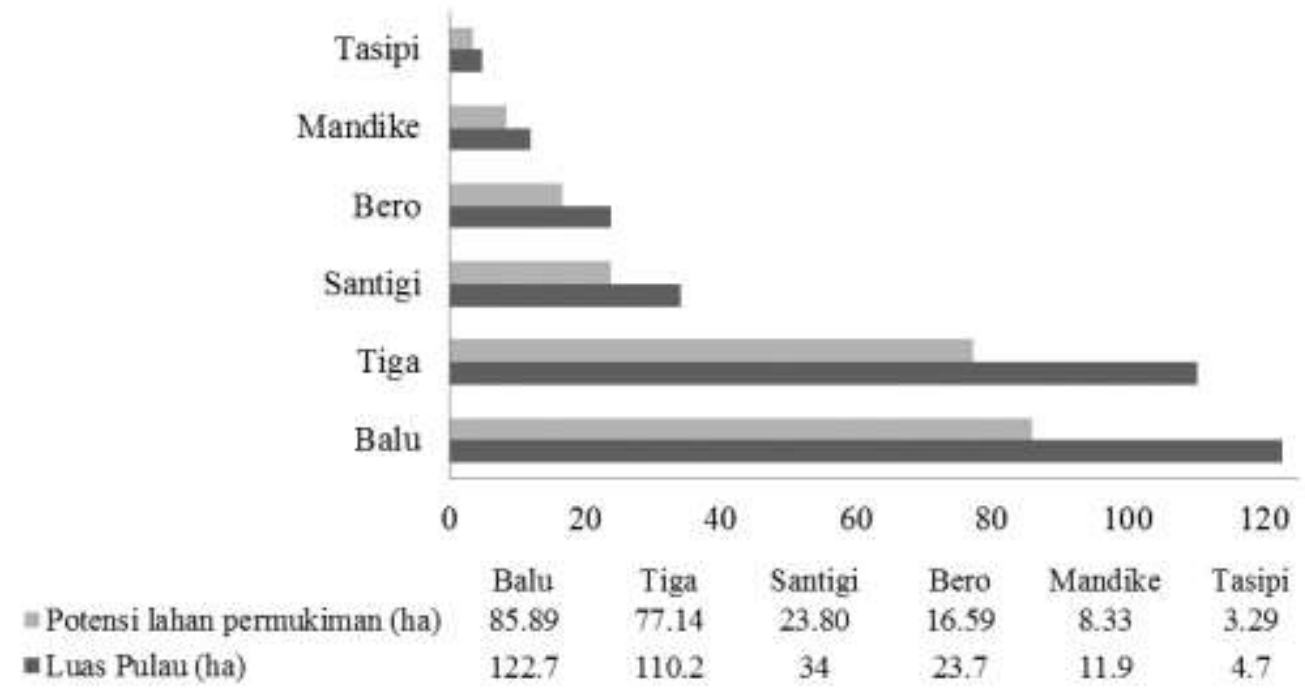

Gambar 2. Potensi lahan pemukiman penduduk pulau kecil (sumber: analisis data 2019). 


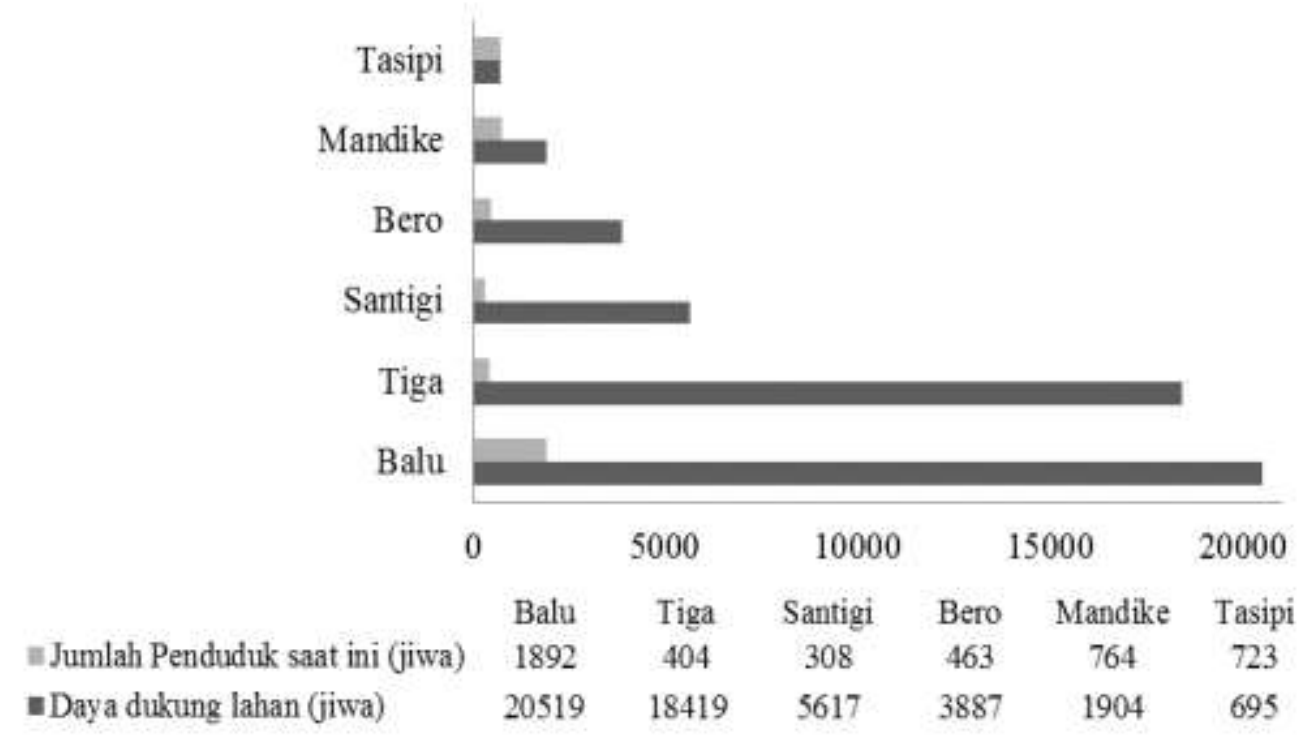

Gambar 3. Daya dukung lahan pulau-pulau kecil (sumber: analisis data 2019).

Bentuk pemanfaatan lahan di daratan Kepulauan Tiworo saat ini adalah pemukiman penduduk. Berdasarkan Peraturan Menteri Kelautan dan Perikanan No. 20 tahun 2008 pemukiman penduduk merupakan salah satu bentuk pemanfaatan lahan yang boleh dilakukan di pulau kecil. Namun demikian, Menteri Agraria dan Tata Ruang membatasi pemanfaatan lahan di pulau kecil dengan mengalokasikan minimal $30 \%$ dari luas pulau untuk kawasan lindung (Permen ATR No 17/2016). Mengacu pada peraturan tersebut, maka potensi lahan yang dapat dimanfaatkan untuk permukiman penduduk dapat ditentukan sebagaimana disajikan pada Gambar 2.

Gambar 2 menunjukkan bahwa pulau yang memiliki ukuran luas lebih besar juga memiliki potensi lahan yang lebih besar untuk dimanfaatkan sebagai lahan permukiman. Berdasarkan analisis kebutuhan ruang minimum setiap individu, daya dukung lahan pulau-pulau kecil sesuai dengan potensi lahan permukiman tersebut disajikan pada Gambar 3.

Berdasarkan Gambar 2 dan Gambar 3 menunjukkan bahwa pulau yang memiliki ukuran lebih besar, juga memiliki potensi lahan dan daya dukung yang lebih besar untuk permukiman. Meskipun pulau yang berukuran lebih besar memiliki potensi dan daya dukung yang lebih besar untuk permukiman penduduk, namun belum tentu memiliki jumlah penduduk yang lebih besar pula. Sebagai contoh di Pulau Tasipi dan Pulau Mandike yang memiliki jumlah penduduk terbesar kedua dan ketiga, tetapi memiliki ukuran luas lebih kecil dibandingkan pulau-pulau kecil lainnya. Hal ini menunjukkan bahwa preferensi penduduk Kepulauan Tiworo terhadap pulau yang lebih besar relatif kecil, sehingga pulau yang berukuran lebih kecil justru memiliki jumlah penduduk yang lebih besar.

Berdasarkan observasi lapangan yang dilakukan, pemanfaatan lahan di daratan pulau hanya digunakan sebagai tempat pemukiman penduduk. Hal ini dapat dilihat dari kontribusi setiap rumah tangga terhadap degradasi lahan tergolong kecil berkisar antara 217-569 $\mathrm{m}^{2}$ sebagaimana ditampilkan Gambar 4. Tingkat degradasai lahan atau luas lahan yang termanfaatkan tersebut sudah termasuk lahan yang digunakan untuk fasilitas umum seperti bangunan sekolah, sarana ibadah, fasilitas kesehatan, dan kantor pemerintahan. Meskipun secara keseluruhan tingkat degradasi lahan baru mencapai 31,45 ha atau $11,73 \%$ dari total luas pulau, namun tingkat pemanfaatan atau degradasi lahan 
yang terjadi di Pulau Tasipi dan Pulau Mandike telah mencapai $100 \%$. Kedua pulau tersebut memiliki tingkat kepadatan penduduk yang lebih tinggi dibanding penduduk pulau lainnya. Tingkat pemanfaatan lahan dan rata-rata akses lahan setiap unit rumah tangga yang terjadi disetiap pulau kecil disajikan secara lengkap pada Gambar 4.

Pemanfaatan lahan pulau kecil untuk pemukiman penduduk sesuai dengan daya dukung lahan memberikan respon terhadap perubahan mutu air. Dampak yang ditimbulkan berupa limbah domestik dapat mengakibatkan peningkatan konsentrasi bahan pencemar yang masuk ke perairan.
Konsentrasi amonia di perairan merupakan parameter kualitas perairan yang memiliki korelasi dengan jumlah penduduk di gugus Kepulauan Tiworo (Ketjulan et al., 2019). Hasil analisis yang dilakukan oleh Ketjulan et al. (2019) menemukan bahwa setiap individu yang mendiami gugus Kepulauan Tiworo memberikan kontribusi berupa peningkatan nilai rasio baku mutu amonia sebesar 2,34 $\times 10^{-5}$, dan nilai konstanta amonia di perairan sebesar 0,07. Jika asumsi pertumbuhan penduduk sebesar $1,36 \%$ per tahun sesuai dengan tingkat pertumbuhan penduduk saat ini, tren peningkatan nilai RBM amonia disajikan pada Gambar 5 berikut.

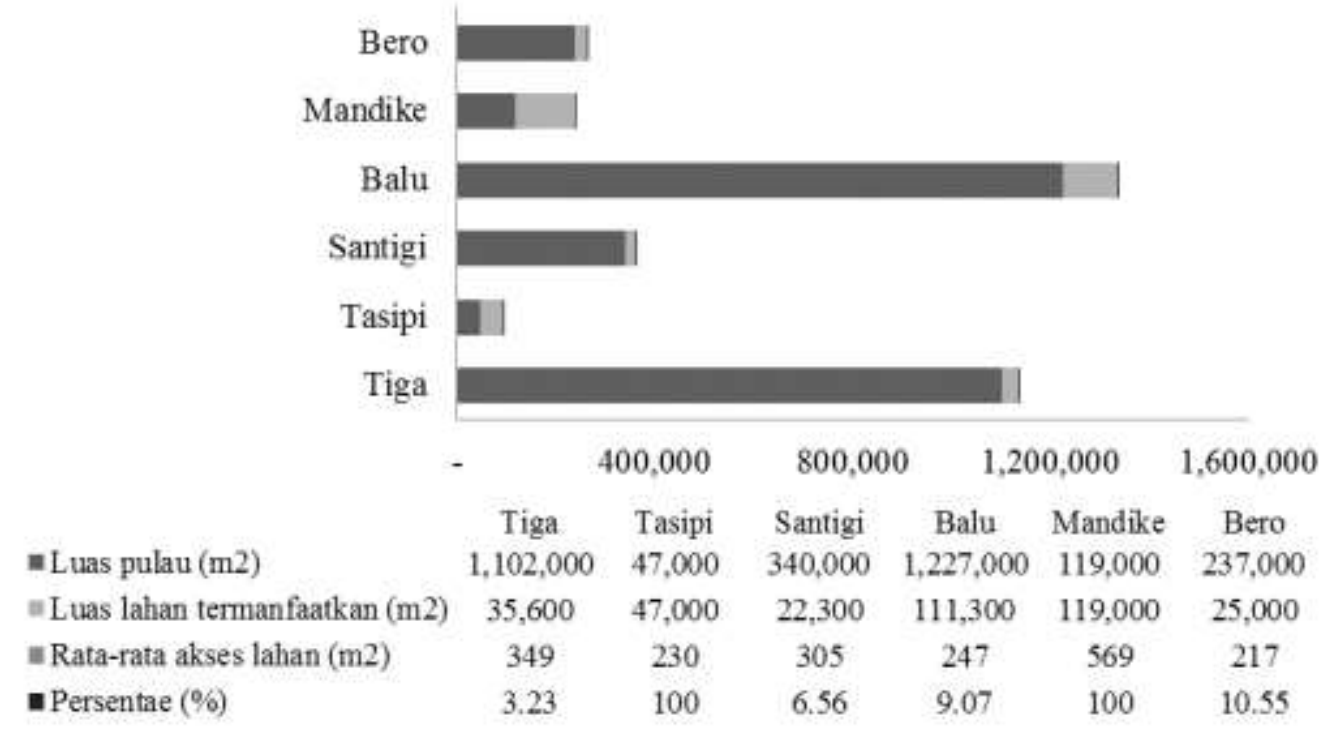

Gambar 4. Tingkat pemanfaatan lahan Kepulauan Tiworo (sumber: analisis data 2019).

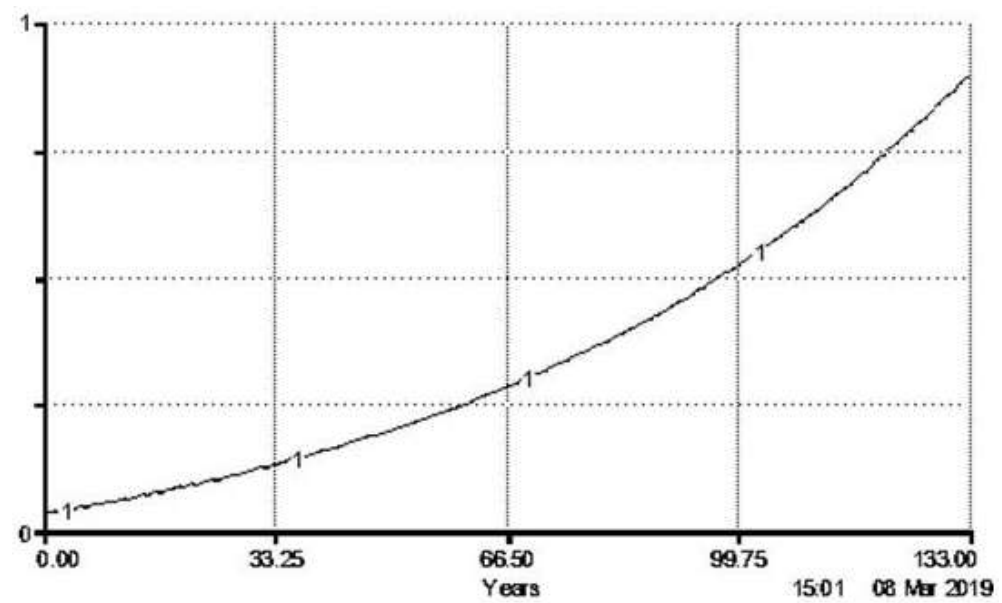

(A) 


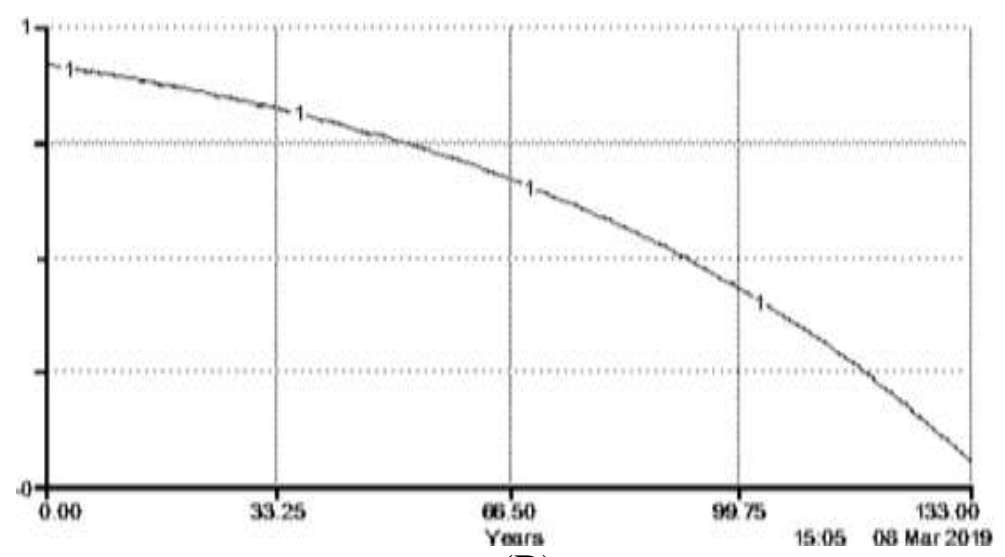

(B)

Gambar 5. (A) Tren peningkatan RBM amonia, (B) tren penurunan daya dukung perairan (Sumber: Ketjulan et al., 2018).

Gambar 5 A menunjukkan tren peningkatan RBM amonia di perairan yang ditunjukan pada sumbu y akan mengalami peningkatan seiring dengan berjalannya waktu dan terjadinya pertambahan jumlah penduduk yang tunjukan pada sumbu $\mathrm{x}$. Hal ini mengakibatkan tren penurunan daya dukung atau penurunan mutu perairan sebagaimana yang ditampilkan pada Gambar 5B.

Hasil penelitian Ketjulan et al. (2019) menunjukkan bahwa nilai RBM amonia pada persamaan $\mathrm{RBM}=0,07+2,34 \times 10^{-5}(\mathrm{Pi})$ belum melebihi nilai RBM yang ditetapkan (RBM < 1). Nilai 0,07 adalah nilai konstan (a) yang menunjukkan nilai $\mathrm{RBM}$ amonia secara alami di perairan, sedangkan 2,34 $\mathrm{x}$ $10^{-5}$ adalah nilai koefisien regrasi (b) yang menunjukkan besarnya kontribusi setiap penduduk terhadap besarnya nilai RBM amonia. Berdasarkan persamaan tersebut, maka proyeksi nilai RBM amonia ber- dasarkan jumlah penduduk saat ini, dan proyeksi berdasarkan jumlah penduduk yang sesuai dengan daya dukung lahan pulau kecil disajikan pada Tabel 1 .

Proyeksi nilai RBM amonia berdasarkan jumlah penduduk yang sesuai dengan daya dukung lahan pada Tabel 1 menunjukkan bahwa jumlah penduduk saat ini maupun proyeksi jumlah penduduk sesuai daya dukung lahan masih berada dibawah ambang baku mutu air. Hal ini memberikan gambaran bahwa jika pemukiman penduduk di pulau-pulau kecil sesuai dengan daya dukung lahan, maka nilai RBM amonia disetiap pulau-pulau kecil masih berada dibawah baku mutu (RBM > 1). Demikian pulau dengan permukiman penduduk di Pulau Tasipi, dimana walaupun jumlah penduduk telah melebihi daya dukung lahan, namun nilai $\mathrm{RBM}$ amonia hanya sebesar $0,086(\mathrm{RBM}<1)$.

Tabel 1. Proyeksi nilai RBM amonia pulau-pulau kecil.

\begin{tabular}{llcccc}
\hline No. & Pulau & $\begin{array}{c}\text { Jumlah } \\
\text { Penduduk } \\
\text { (jiwa) }\end{array}$ & $\begin{array}{c}\text { Daya Dukung } \\
\text { Lahan (jiwa) }\end{array}$ & $\begin{array}{c}\text { Proyeksi RBM Amonia } \\
\text { Sesuai Jumlah } \\
\text { Penduduk Saat Ini }\end{array}$ & $\begin{array}{c}\text { Sesuai Daya } \\
\text { Dukung Lahan }\end{array}$ \\
\hline 1. & Tiga & 404 & 18.419 & 0,079 & 0,501 \\
2. & Tasipi & 723 & 695 & 0,087 & 0,086 \\
3. & Santigi & 308 & 5617 & 0,077 & 0,201 \\
4. & Balu & 1.892 & 20519 & 0,114 & 0,550
\end{tabular}




\begin{tabular}{cccccc}
\hline No. & Pulau & $\begin{array}{c}\text { Jumlah } \\
\text { Penduduk } \\
\text { (jiwa) }\end{array}$ & $\begin{array}{c}\text { Daya Dukung } \\
\text { Lahan (jiwa) }\end{array}$ & $\begin{array}{c}\text { Proyeksi RBM Amonia } \\
\text { Sesuai Jumlah } \\
\text { Penduduk Saat Ini }\end{array}$ & $\begin{array}{c}\text { Sesuai Daya } \\
\text { Dukung Lahan }\end{array}$ \\
\hline 5. & Mandike & 764 & 1904 & 0,088 & 0,115 \\
6. & Bero & 463 & 3887 & 0,081 & 0,161 \\
\hline
\end{tabular}

Sumber: analisis data 2019.

\subsection{Pembahasan}

Pemukiman penduduk di Kepulauan Tiworo merupakan bentuk pemanfaatan ruang yang dilakukan oleh masyarakat lokal. Total 14 pulau kecil yang berada di wilayah administrasi Kecamatan Tiworo Utara, 6 pulau diantaranya telah dimanfaatkan untuk pemukiman penduduk. Aktivitas pemukiman penduduk yang dilakukan merupakan single use activity, karena jenis kegiatan pemanfaatan lainnya seperti pariwisata bahari, dan kegiatan pertanian tidak dilakukan diwilayah tersebut. Tingkat pemanfaatan lahan secara umum masih tergolong rendah, sebesar 31,45 ha atau $11,73 \%$ dari total keseluruhan pulau-pulau kecil berpenduduk. Rendahnya tingkat pemanfaatan lahan karena jumlah penduduk tergolong rendah dengan tingkat kepadatan berkisar antara 4-154 ind/ha.

Meskipun pemanfaatan lahan masih tergolong rendah, namun pemanfaatan lahan di Pulau Tasipi dan Pulau Mandike telah mencapai $100 \%$. Kedua pulau tersebut memiliki tingkat kepadatan penduduk yang lebih besar dibandingkan dengan kepadatan pulau-pulau kecil lainnya. Selain itu, kedua tersebut merupakan pulau yang berukuran paling kecil dibandingkan pulau-pulau kecil berpenduduk lainnya. Oleh karena memiliki ukuran yang lebih kecil, tentu memiliki daya dukung yang lebih kecil pula. Luas Pulau Tasipi sebesar 4,7 ha memiliki lahan potensial untuk permukiman penduduk sebesar 3,29 ha, yang dapat menampung penduduk sesuai SNI 03-1733-2004 sebesar 695 jiwa.

Saat ini pemanfaatan lahan di Pulau Tasipi telah melebihi daya dukung lahan, bahkan tidak ada lagi peruntukan lahan sebesar 30\% untuk kawasan lindung sebagaimana diatur dalam Peraturan Menteri Agraria dan Tata Ruang tahun 2016. Jumlah penduduk di pulau tersebut saat ini berjumlah 723 jiwa telah melebihi daya dukung lahan. Sementara itu jumlah penduduk di Pulau Mandike meskipun belum melebihi daya dukung lahan, tetapi tingkat pemanfaatan lahan atau lahan yang terdegradasi sudah mencapai $100 \%$. Jumlah penduduk saat ini sebesar 764 jiwa masih lebih kecil dari daya dukung lahan sebesar 1.904 jiwa. Tingginya tingkat pemanfaatan lahan di pulau ini disebabkan rata-rata akses lahan setiap unit rumah tangga lebih besar dibandingkan pulau-pulau kecil lainnya sebagaimana ditampilkan pada Gambar 4.

Karakteristik Kepulauan Tiworo yang berukuran sangat kecil, dengan ukuran berkisar antara 0,047-1,27 km², menjadikan ketersediaan lahan merupakan faktor pembatas. Meskipun ketersediaan lahan di pulau kecil menjadi faktor pembatas, namun preferensi penduduk Kepulauan Tiworo tidak berkaitan dengan pulau yang berukuran lebih besar. Hal ini memberikan kesan bahwa penduduk Kepulauan Tiworo tidak memiliki ketergantungan terhadap ketersediaan lahan. Kecenderungan masyarakat Kepulauan Tiworo mengakses sumberdaya lahan hanya digunakan untuk mendirikan bangunan rumah tinggal. Rata-rata akses lahan setiap rumah tangga berkisar antara 217-569 $\mathrm{m}^{2}$, sudah termasuk lahan untuk fasilitas umum seperti bangunan sekolah, kantor pemerintahan, sarana ibadah, dan sarana untuk fasilitas kesehatan. Fasilitas umum yang tersedia di gugus pulau kecil berpenduduk berupa sekolah dasar (SD), sekolah lanjutan tingkat pertama (SLTP), kantor pemerintahan, puskesmas pembantu, dan sarana ibadah. Berdasarkan standar 
nasional Indonesia, kebutuhan lahan keseluruhan fasilitas umum tersebut sebesar $3.960 \mathrm{~m}^{2}$. Akses lahan setiap rumah tangga yang relatif kecil menggambarkan tingkat degradasi atau alih fungsi lahan juga relatif kecil. Kondisi berbeda ditunjukkan di pemukiman penduduk Pulau Pramuka Kepulauan Seribu, dimana dinamika pemanfaatan lahan yang paling sering terjadi adalah penggunaan lahan yang belum terpakai/lahan kosong, dan juga perubahan fungsi lahan dari fungsi yang satu menjadi fungsi lainnya (Nurjanah, 2012).

Rendahnya preferensi penduduk terhadap pulau yang berukuran lebih luas diduga disebabkan oleh beberapa hal, yakni: (1) Setiap penduduk hanya memiliki hak ulayat pada pulau kecil dimana mereka tinggal menetap. Pengakuan hak-hak adat masyarakat tersebut diakui secara konstitusi, yang telah tertuang dalam pasal 18B UUD 1945 bahwa negara mengakui dan menghormati kesatuan kesatuan masyarakat hukum adat beserta hak hak tradisionalnya sepanjang masih hidup dan sesuai dengan perkembangan masyarakat. Bagian-bagian dari tanah hak bersama tersebut dapat diberikan kepada orang dan badan hukum tertentu (Hutagalung dan Gunawan, 2009). (2) Telah terbentuknya ikatan jejaring sosial antar masyarakat disuatu pulau, sehingga masyarakat tidak ingin meninggalkan pulau kecil yang sudah dihuni selama bertahuntahun. Memanfaatkan jejaring sosial bagi masyarakat merupakan salah satu strategi adaptasi terhadap perubahan lingkungan (Helmi dan Satria, 2012; Petzold and Ratter, 2015). (3) Karakteristik gugus Kepualaun Tiworo adalah pulau berpasir yang tidak memungkinkan untuk dimanfaatkan sebagai sumber pendapatan tambahan seperti melalui kegiatan pertanian dan peternakan. Hal ini menyebabkan tidak adanya kecenderungan masyarakat untuk mengakses lahan yang lebih besar. Kondisi ini berbeda dengan pemanfaatan lahan oleh masyarakat di Pulau Masalembu yang memanfaatkan lahan sebagai alternatif penghasilan, yang kemudian beralih menjadi komoditas unggulan (Pinuji et al., 2018). Menurut Mekonnen et al. (2018) dan Rotinsulu et al. (2018) pertanian dan pemukiman penduduk merupakan elemen utama yang berkaitan dengan penggunaan lahan. (4) akses terhadap lokasi penangkapan, dimana wilayah penangkapan yang memiliki jarak yang relatif lebih dekat lebih menguntungkan dibandingkan dengan wilayah tangkapan yang jauh.

Meskipun tingkat kepadatan penduduk di Kepulauan Tiworo masih tergolong rendah, namun keberadaannya memiliki keterkaitan terhadap degradasi lahan. Tingkat kepadatan penduduk di setiap pulau menunjukkan korelasi yang positif terhadap tingkat degradasi lahan. Semakin besar tingkat kepadatan penduduk, degradasi lahan yang terjadi juga lebih besar (Luo et al., 2017; Gibson, 2018; Du dan Huang, 2017). Secara keseluruhan degradasi lahan yang terjadi telah mencapai 31,45 ha atau $11,73 \%$, namun di Pulau Tasipi dan Pulau Mandike telah mengalami degradasi lahan yang mencapai $100 \%$. Kedua pulau tersebut memiliki ukuran yang lebih kecil dibandingkan pulau berpenduduk lainnya. Secara umum rendahnya tingkat pemanfaatan lahan menunjukkan bahwa lahan pulau kecil hanya dimanfaatkan untuk pemukiman penduduk.

Total jumlah penduduk Kepulauan Tiworo saat ini sebesar 4.554 jiwa relatif kecil dibandingkan dengan daya dukung lahan. Total daya dukung lahan pulau kecil berpenduduk sebesar 51.039 jiwa, sedangkan total daya dukung lahan yang tersedia dan belum dimanfaatkan sebesar 46.485 jiwa, lebih besar dari jumlah penduduk saat ini. Jika pertumbuhan penduduk sebesar $1,36 \%$ per tahun (pertumbuhan penduduk saat ini), tentunya pulau yang berukuran lebih kecil dan memiliki tingkat kepadatan penduduk lebih tinggi akan lebih cepat over kapasitas di-bandingkan pulau dengan kepadatan penduduk lebih rendah. Dari 6 pulau yang berpenduduk, Pulau Tasipi memiliki ukuran 
yang paling kecil, dan tingkat kepadatan penduduk yang paling tinggi. Jumlah penduduk di pulau tersebut sebesar 723 jiwa, telah melebihi daya dukung lahan (644 jiwa). Sementara itu di Pulau Mandike meskipun tingkat pemanfaatan lahan telah mencapai $100 \%$ namun jumlah penduduk masih dibawah daya dukung lahan. Tingginya tingkat pemanfaatan lahan bukan karena jumlah penduduk yang melebihi daya dukung lahan seperti halnya di Pulau Tasipi, tetapi karena rata-rata akses lahan setiap rumah tangga lebih besar dibandingkan ratarata akses lahan di pulau kecil lainnya. Sedangkan Pulau Tiga dan Pulau Balu adalah pulau yang memiliki daya dukung lahan yang lebih besar dibanding pulau kecil berpenduduk lainnya. Kepadatan penduduk yang tinggi, berpotensi akan terjadinya alih fungsi lahan pulau kecil yang tidak berpenduduk sebagai tempat pemukiman penduduk. Fenomena per-tambahan jumlah penduduk akan menambah kompleksitas persoalan yang terjadi di wilayah pesisir dan pulau pulau kecil (Diposaptono, 2015).

Implikasi permukiman penduduk juga berkaitan dengan perubahan mutu air. Hasil analisis rasio baku mutu yang dilakukan oleh Ketjulan et al. (2019) menunjukkan adanya pengaruh yang nyata jumlah penduduk Kepulauan Tiworo terhadap konsentrasi amonia di perairan. Kontribusi setiap penduduk pulau kecil terhadap nilai RBM amonia di perairan sebesar 2,34 x $10^{-5}$. Berdasarkan besarnya nilai koefisien tersebut, maka nilai RBM dugaan sesuai jumlah penduduk saat ini berkisar antara 0,077-0,114. nilai tersebut masih lebih kecil dari 1, yang menunjukkan bahwa perairan belum tercemar oleh amonia. Besarnya nilai RBM dugaan tersebut tentunya semakin bertambah seiring dengan pertambahan jumlah penduduk.

Pertumbuhan penduduk yang berakibat pada pertambahan jumlah penduduk pulau-pulau kecil juga berimplikasi terhadap penurunan mutu air. Ketjulan et al. (2019) menyebutkan bahwa setiap pertambahan satu individu penduduk pulau-pulau kecil di Selat Tiworo mengakibatkan peningkatan nilai RBM amonia sebesar 2,34 x $10^{-5}$. Limbah organik yang dihasilkan oleh penduduk pulau-pulau kecil yang diduga mengandung senyawa nitrogen akan terdekomposisi menjadi ion-ion yang lebih sederhana. Menurut Fitzgerald et al. (2014); Jianlong et al. (2004); Effendi (2003); Garrido et al. (1997) limbah nitrogen hasil dekomposisi bahan organik oleh mikroba merupakan sumber amonia di perairan. Jika pertumbuhan penduduk Kepulauan Tiworo sebesar $1,36 \%$ per tahun, maka nilai RBM amonia akan mencapai angka 1 dalam jangka waktu 133 tahun kedepan sebagaimana ditampilkan pada Gambar 5. Hal ini menunjukkan bahwa peningkatan populasi penduduk yang menghasilkan limbah domestik, memiliki keterkaitan dengan peningkatan konsentrasi bahan organik yang terkandung dalam air (Chen, 2018; Cao et al., 2017). Estimasi peningkatan nilai RBM dan daya dukung amonia tersebut merupakan kondisi aktual saat ini, dimana tidak dilakukan intervensi terhadap jumlah penduduk sebagai salah satu sumber bahan organik. Besarnya daya dukung perairan pulau-pulau kecil yang mencapai 39.852 jiwa menunjukkan bahwa kapasitas asimilasi badan air dalam mengurai material organik lebih besar dibandingkan dengan input bahan organik, sehingga tidak mengakibatkan perairan menjadi tercemar.

\section{KESIMPULAN}

Secara umum pemanfaatan lahan sebagai tempat pemukiman penduduk di gugus Kepulauan Tiworo masih berada dibawah daya dukung lahan, kecuali di Pulau Tasipi dan Pulau Mandike. Preferensi penduduk terhadap pulau yang berukuran lebih luas tergolong rendah, yang diduga berkaitan dengan hak ulayat, ikatan jejaring sosial, karakteristik lahan darat, dan akses terhadap lokasi penangkapan. Tingkat degradasi lahan juga tergolong rendah, dan 
memiliki korelasi yang signifikan dengan tingkat kepadatan penduduk yang mendiami pulau-pulau kecil. Kecenderungan masyarakat mengakses sumberdaya lahan hanya digunakan sebagai tempat untuk mendirikan bangunan tinggal. Pemanfaatan pulau-pulau kecil untuk pemukiman penduduk sesuai dengan daya dukung lahan tidak akan melebihi ambang baku mutu amonia di perairan. Perspektif pengelolaan besarnya daya dukung perairan gugus Kepulauan Tiworo yang melebihi daya dukung lahan menunjukkan bahwa ketersediaan lahan di gugus Kepulauan Tiworo merupakan faktor pembatas dalam pengelolaan pulau kecil.

\section{UCAPAN TERIMA KASIH}

Publikasi ini merupakan salah satu bagian dari proses penelitian dalam program studi pengelolaan sumber daya pesisir dan laut di Institut Pertanian Bogor. Penulis ingin mengucapkan terima kasih kepada semua pihak yang telah membantu dalam penelitian ini. Kepada unsur pimpinan Universitas Halu Oleo yang telah memberikan kesempatan belajar, juga kepada tim yang membantu dalam survei lapangan sampai penelitian ini dapat diselesaikan tepat waktu.

\section{DAFTAR PUSTAKA}

Bengen, D.G., A.S.W. Retraubun, dan S. Saad. 2012. Menguak realitas dan urgensi pengelolaan berbasis ekososio sistem pulau-pulau kecil. Bogor: Pusat Pembelajaran dan Pengembangan Pesisir dan Laut (P4L). ISBN 979-98867-2-4.

Cao, W., R. Li, X. Chi, N. Chen, J. Chen, H. Zhang and F. Zhang. 2017. Island urbanization and its ecological consequences: A case study in the Zhoushan Island, East China. Ecological Indicators, 76: 1-14. https://doi.org/10.1016/j.ecolind.2017 .01 .001
Chen, Y.C. 2018. Effects of urbanization on municipal solid waste composition. Waste Management, 79: 828-836. https://doi.org/10.1016/j.wasman.201 8.04.017

Dahuri, R. 2003. Keanekaragaman hayati laut; aset pembangunan berkelanjutan Indonesia. Jakarta: Gramedia. 412 hlm.

Diposaptono, S. 2015. Membangun poros maritim dunia dalam perspektif tata ruang laut. Direktorat Tata Ruang Laut Pesisir dan Pulau-Pulau Kecil. Jakarta, 398 hlm.

Du, X. and Z. Huang. 2017. Ecological and environmental effects of land use change in rapid urbanization: The case of Hangzhou, China. Ecological Indicators, 81: 243-251. https://doi.org/10.1016/j.ecolind.2017 .05 .040

Effendi, H. 2003. Telaah kualitas air bagi pengelolaan sumberdaya dan lingkungan perairan. Kanisius. Jakarta. 259 hlm. ISBN:979-21-06138.

Fauzi, A. 2002. Valuasi ekonomi sumberdaya pulau-pulau kecil. Makalah disampaikan pada seminar peluang investasi pulau-pulau kecil di indonesia. Jakarta 10 Oktober 2002.

Fitzgerald, C.M., P. Camejo, J.Z. Oshlag, and D.R. Noguera. 2015. Ammoniaoxidizing microbial communities in reactors with efficient nitrification at low-dissolved oxygen. Water Research, 70: 38-51. https://doi.org/10.1016/j.watres.2014. 11.041

Food and Agriculture Organization (FAO). 2007. The world's mangroves 19802005. Rome: Food and Agriculture Organization of the United Nations. $153 p$.

Garrido, J.M., W.A.J. van Benthum, M.C.M. van Loosdrecht, and J.J. Heijnen. 1997. Influence of dissolved oxygen concentration on nitrite accumulation 
in a biofilm airlift suspension reactor. Biotechnology and Bioengineering, 53: 168-178.

https://doi.org/10.1002/(SICI)10970290(19970120)53:2<168::AIDBIT6>3.0.CO;2-M

Gibson, J. 2018. Forest loss and economic inequality in the solomon islands: Using small- area estimation to link environmental change to welfare outcomes. Department of Economics, University of Waikato, New Zealand. Ecological Economics, 148: 66-76. https://doi.org/10.1016/j.ecolecon.201 8.02.012

Helmi, A. dan A. Satria. 2012. Strategi adaptasi nelayan terhadap perubahan ekologis. Makara. Sosial Humaniora, 16(1):68-78

Hutagalung, A.S. dan M. Gunawan. 2009. Kewenangan pemerintah di bidang pertanahan. Rajawali Pers. Jakarta. $224 \mathrm{hlm}$.

Jianlong, W. and Y. Ning. 2004. Partial nitrification under limited dissolved oxygen conditions. Process Biochemistry, 3(10): 1223-1229. https://doi.org/10.1016/S00329592(03)00249-8

Kementerian Kelautan dan Perikanan. 2008. Peraturan Menteri Kelautan dan Perikanan Republik Indonesia Nomor PER.20/MEN/2008 Tentang pemanfaatan pulau-pulau kecil dan perairan di sekitarnya. Jakarta. 17 November 2008.

Ketjulan, R., Z. Imran, M. Boer, and V.P. Siregar. 2019. Estimation of water carrying capacity for settlement activities in small islands. case study: small islands of North Tiworo District, Muna Regency, Indonesia. $J$. Nature Environment and Pollution Technology, 18(2): 435-443.

Kurniawan, F., L. Adrianto, D.G. Bengen, and L.B. Prasetyo. 2016. Vulnerability assessment of small islands to tourism: The case of the
Marine Tourism Park of the Gili Matra Islands. Indonesia. Global Ecology and Conservation, 6: 308326.

https://doi.org/10.1016/j.gecco.2016.0 4.001

Krisnohadi, A. 2011. Tekanan penduduk dan trend perubahan penggunaan lahan potensial untuk pertanian di Kota Singkawang Kalimantan Barat. Prosiding Seminar Nasional Budidaya Pertanian. Urgensi dan Strategi Pengendalian Alih Fungsi Lahan Pertanian. Bengkulu 7 Juli 2011. 3643 hlm. ISBN 978-602-19247-0-9.

Lambin, E.F., B.L. Turner, H.J. Geista, S.B. Agbola, A. Angelsend, J.W. Bruce, O.T. Coomes, R. Dirzo, G. Fischer, C. Folkei, P.S. George, K. Homewood, J. Imbernon, R. Leemans, X. Li, E.F. Moran, M. Mortimore, P.S. Ramakrishnan, J.F. Richards, H. Skanes, W. Steffen, G.D. Stone, U. Svedin, T.A. Veldkamp, C. Vogel, and J. Xuy. 2001. The causes of landuse and land-cover change: moving beyond the myths. Global Environmental Change, 11: 261-269.

Luo, J., X. Zhang, Y. Wu, J. Shen, L. Shen, and X. Xing. 2017. Urban land expansion and the floating population in China: For production or for living?. Cities, 74: 219-228. https://doi.org/10.1016/j.cities.2017.1 2.007

Mekonnen, Z., H. Tadesse, T. Woldeamanuel, Z. Asfaw, and H. Kassa. 2018. Land use and land cover changes and the link to land degradation in Arsi Negele district, Central Rift Valley, Ethiopia. Remote Sensing Applications: Society and Environment. 12: 1-9. https://doi.org/10.1016/j.rsase.2018.0 7.012

Menteri Negara Lingkungan Hidup. 2004. Keputusan Menteri Negara Lingkungan Hidup Nomor 51 Tahun 
2004 tentang baku mutu air laut untuk biota laut. Jakarta: KLH.

Meyer, W.B. and B.L. Turner. 1992. Human population growth and global landuse/cover change. Graduate School of Geography and George Perkins Marsh Institute, Clark University. Annu. Rev. Ecol. Syst, 23: 39-61.

Nurjanah, R. 2012. Studi persepsi dampak perubahan pemanfaatan lahan terhadap kunjungan wisata di pulau pramuka kepulauan seribu. $J$. Perencanaan Wilayah dan Kota, 23 (2): 139-156.

Peraturan Menteri Agraria dan Tata Ruang Republik Indonesia Nomor 17 Tahun 2016. Penataan pertanahan di wilayah pesisir dan pulau-pulau kecil. Jakarta. 14 April 2016.

Petzold, J. and B.M.W Ratter. 2015. Climate change adaptation under a social capital approach Ananalytical framework for small islands. Review. Ocean \& Coastal Management, 112: 36-43.

https://doi.org/10.1016/j.ocecoaman.2 015.05.003

Pinuji, S., M.A. Suhartanto, dan T. Arianto. 2018. Dinamika dan tantangan penggunaan dan pemanfaatan tanah di wilayah pulau kecil. J. Agraria dan Pertanaha, 4(1): 102-114. http://dx.doi.org/10.31292/jb.v4i1.21 8
Pindyck, R.S. and D.L. Rubinfeld. 1998. Econometric models and economic forecast. Irwin McGraw-Hill. p 634.

Rahman, A. 2009. Analisis kerentanan pulau-pulau kecil berbasis spasial di kawasan Selat Tiworo Provinsi Sulawesi Tenggara. Bogor. IPB. 149 hlm.

Rotinsulu, W., H. Walangitan, dan A. Ahmad. 2018. Analisis perubahan tutupan lahan daerah aliran sungai Tondano, Sulawesi Utara Selama Periode Tahun 2002 dan 2015. J. Pengelolaan Sumberdaya Alam dan Lingkungan, 8(2): 161-169. https://doi.org/10.29244/jps1.8.2.161169

Standar Nasional Indonesia (SNI) 03-17332004. Tata cara perencanaan lingkungan perumahan di perkotaan. Badan Standardisasi Nasional 2004.

Wu, S., L.J. Mickley, J.O. Kaplan, and D.J. Jacob. 2012. Impacts of changes in land use and land cover on atmospheric chemistry and air quality over the $21^{\text {st }}$ century. Atmos. Chem. Phys, 12: 1597-1609. https://doi.org/10.5194/acp-12-15972012

Received :02 April 2019

Reviewed : 14 May 2019

Accepted : 05 September 2019 